\title{
Investigation of air pollutants in rural nursery school - a case study
}

\author{
Anna Mainka ${ }^{1, *}$, Elwira Zajusz-Zubek ${ }^{1}$, Barbara Kozielska ${ }^{1}$, and Ewa Brągoszewska $^{1}$ \\ ${ }^{1}$ Department of Air Protection, Silesian University of Technology, 22B Konarskiego St., 44-100 \\ Gliwice, Poland
}

\begin{abstract}
Children's exposure to air pollutants is an important public health challenge. Indoor air quality (IAQ) in nursery school is believed to be different from elementary school. Moreover, younger children are more vulnerable to air pollution than higher grade children because they spend more time indoors, and their immune systems and bodies are less mature. The purpose of this study was to evaluate the indoor air quality (IAQ) at naturally ventilated rural nursery schools located in Upper Silesia, Poland. We investigated the concentrations of volatile organic compounds (VOCs), particulate matter (PM), bacterial and fungal bioaerosols, as well as carbon dioxide $\left(\mathrm{CO}_{2}\right)$ concentrations in younger and older children's classrooms during the winter and spring seasons. The concentration of the investigated pollutants in indoor environments was higher than those in outdoor air. The results indicate the problem of elevated concentrations of $\mathrm{PM}_{2.5}$ and $\mathrm{PM}_{10}$ inside the examined classrooms, as well as that of high levels of $\mathrm{CO}_{2}$ exceeding $1,000 \mathrm{ppm}$ in relation to outdoor air. The characteristics of PM and $\mathrm{CO}_{2}$ levels were significantly different, both in terms of classroom occupation (younger or older children) and of season (winter or spring).
\end{abstract}

\section{Introduction}

One of the five EU benchmarks for Education and Training (ET 2020) is that by 2020, at least $95 \%$ of children between the ages of four and starting compulsory primary education should participate in early childhood education [1]. In the context of expanding early childhood education, the EU should be active in reviewing research pertaining to the quality of care afforded to the system's youngest participants, which is linked in particular with the microenvironment of nursery schools. There, they are exposed to unknown levels of indoor pollutants. Children are particularly vulnerable to air pollutants, because they spend more time indoors than active, healthy adults, moreover they breath higher volumes of air relative to their body weights and their tissue and organs are growing [2].

Many research that consider children underline the relation between IAQ (indoor air quality) and health effects [3].

Among indoor pollutants researchers point out volatile organic compounds (VOCs), particulate matter (PM), especially finer particles (particles with an aerodynamic diameter smaller than $2.5 \mu \mathrm{m}, \mathrm{PM}_{2.5}$ and smaller than $1 \mu \mathrm{m}, \mathrm{PM}_{1}$ ), bioaerosols as well as

* Corresponding author: anna.mainka@polsl.pl 
temperature and relative humidity to provide thermal comfort [4]. Carbon dioxide $\left(\mathrm{CO}_{2}\right)$, although not defined as an air pollutant, is an indicator of low ventilation rates [5]. Increased levels of $\mathrm{CO}_{2}$ led to a decrease in pupils' learning abilities of approximately $5 \%$ and communicate with respiratory illnesses [6].

In addition to air pollutants emitted indoors and penetrating from outdoors, ASHRAE Standard [7] points that some materials act as sinks for emissions and then become secondary sources of VOCs and PM as they reemit adsorbed pollutants. The sink materials include fabric partitions and other fleecy materials. The specific sorptive properties of soft materials are particularly relevant in the case of nursery schools, especially in younger children's classrooms, where except for carpets, there are many sorptive toys and additional materials such as bedcovers for the duration of an afternoon nap [8].

The aim of the present study is to characterize IAQ in rural nursery school located near Gliwice, in southern Poland. The study carried out simultaneous measurements of:

- VOCs (particularly benzene, toluene, ethylbenzene and xylenes - BTEX),

- PM (indoor: $\mathrm{PM}_{1}, \mathrm{PM}_{2.5}, \mathrm{PM}_{10}$ and total - TSP; outdoor: $\mathrm{PM}_{2.5}$ and $\mathrm{PM}_{10}$ ),

- bioaerosols (culturable bacterial and fungal aerosols),

- $\mathrm{CO}_{2}$ concentration (outdoors and indoor in two classrooms) with physical parameters (temperature and relative humidity)

in naturally ventilated classrooms occupied by younger and older children classrooms during winter and spring seasons. The emphasis of this article will be on the difference between winter and spring seasons as well as younger and older children classrooms.

\section{Materials and methods}

The study was carried out rural nursery school situated about $10 \mathrm{~km}$ north of the city of Gliwice (Figure 1), which is located in the west district of the industrial region of Upper Silesia, Poland. The major activities influencing the ambient air quality of this site are agricultural activities (during non-heating periods) and burning of biomass and fossil fuels for domestic needs (during heating periods).

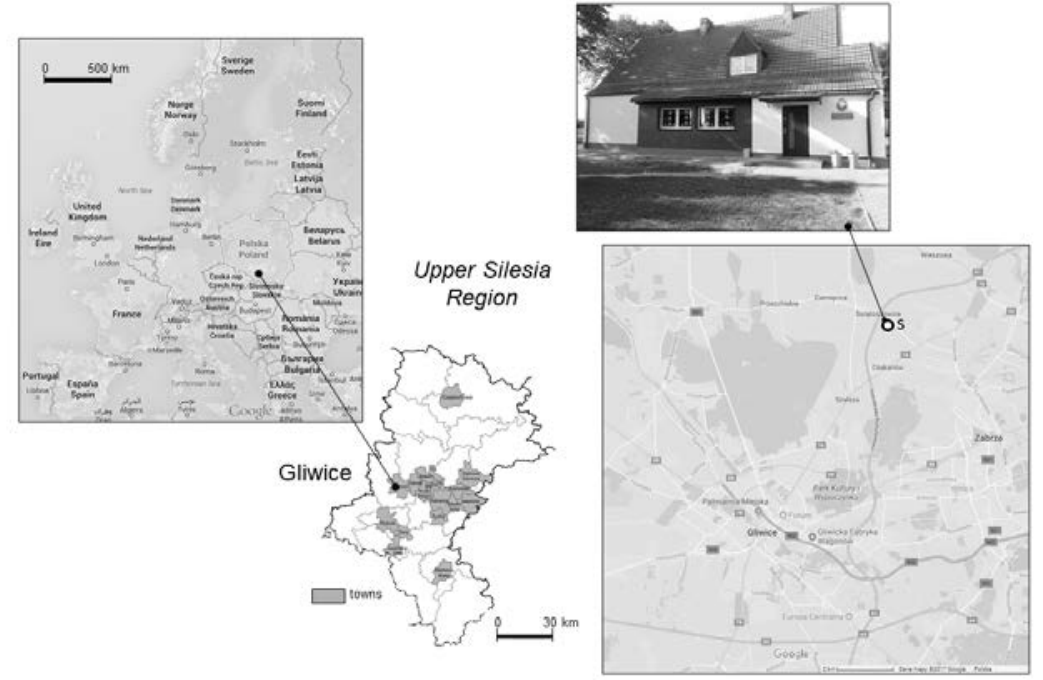

Fig. 1. Location of the investigated nursery school (Map data: 2017@ Google, ORION-ME).

The building is located $50 \mathrm{~m}$ from the A1 highway. It is separated from the highway by highway screens. It is a detached building (Figure 1) that underwent thermal efficiency 
improvement processes, completed in the summer of 2013. During the thermal insulation process, natural ventilation using the buildings' air duct systems was left unchanged. Consequently, the IAQ is primarily ensured by means of stack ventilation and airing through open and unsealed windows. The measurements were conducted in both the classrooms of older (five- to six-year-old, I) and younger (three- to four-year-old, II) children. Table 1 summarizes the specification of the two sampling sites, including basic IAQ parameters and the occupancy of each classroom during the winter and spring seasons.

Table 1. Summary of the occupancy and IAQ parameter characteristics for each studied classroom, as well as for the outdoor air.

\begin{tabular}{|l|c|c|}
\hline \multirow{2}{*}{ Parameters } & \multicolumn{2}{|c|}{ Classroom of Children } \\
\cline { 2 - 3 } & Older (I) & Younger (II) \\
\hline Children's Age, Years & $5-6$ & $3-4$ \\
\hline Floor & Ground floor & Ground floor \\
\hline Volume, $\mathrm{m}^{3}$ & 169.7 & 118.6 \\
\hline Period of Occupation & $6: 30-16: 00$ & $8: 00-12: 30$ \\
\hline Number of children in group & 24 & 21 \\
\hline Median occupancy of children - winter & 16 & 14 \\
\hline Median occupancy of children - spring & 18 & 14 \\
\hline Indoor temperature, ${ }^{\circ} \mathrm{C}$ - winter & $27.8 \pm 3.6$ & $26.2 \pm 2.7$ \\
\hline Indoor temperature, ${ }^{\circ} \mathrm{C}$ - spring & $23.6 \pm 2.7$ & $24.2 \pm 1.9$ \\
\hline Indoor relative humidity $(\mathrm{RH}), \%$ - winter & $24.5 \pm 6.7$ & $26.0 \pm 6.6$ \\
\hline Indoor relative humidity $(\mathrm{RH}), \%$ - spring & $46.5 \pm 5.6$ & $42.5 \pm 4.8$ \\
\hline Indoor $\mathrm{CO}_{2}$ concentration, ppm - winter & $1122.7 \pm 571.0$ & $1265.4 \pm 652.6$ \\
\hline Indoor $\mathrm{CO}_{2}$ concentration, ppm - spring & $1374.5 \pm 825.5$ & $1090.8 \pm 630.8$ \\
\hline \multicolumn{2}{|c|}{ Outdoor parameters, mean \pm SD } \\
\hline Season & winter & spring \\
\hline Temperature, ${ }^{\circ} \mathrm{C}$ & $13.4 \pm 9.2$ & $24.4 \pm 11.6$ \\
\hline Relative humidity $(\mathrm{RH}), \%$ & $47.0 \pm 28.8$ & $54.3 \pm 34.0$ \\
\hline $\mathrm{CO}_{2}$ concentration, ppm & $374.0 \pm 17.1$ & $353.5 \pm 16.2$ \\
\hline
\end{tabular}

The indoor and outdoor concentrations of selected VOCs, different fractions of PM (indoor: $\mathrm{PM}_{1}, \mathrm{PM}_{2.5}, \mathrm{PM}_{10}$ and TSP; outdoor: $\mathrm{PM}_{2.5}$ and $\mathrm{PM}_{10}$ ) and bioaerosols, as well as $\mathrm{CO}_{2}$ concentrations, were measured in the classrooms of younger and older children in the selected building. The sampling position in classrooms was set at the height of an average child's head (i.e., about 0.8 to $1.0 \mathrm{~m}$ above the floor) and away from the door, thus avoiding disturbances resulting from air currents.

Sixteen VOCs (benzene, toluene, ethylbenzene, m-xylene, p-xylene, o-xylene, styrene, isopropylbenzene, n-propylbenzene, 1,3,5-trimethylbenzene, tert-butylbenzene, 1,2,4trimethylbenzene, sec-butylbenzene, 4-isopropyltoluene, n-butylbenzene and naphthalene) were actively sampled using Perkin Elmer stainless steel tube samplers containing Tenax GR according to the US EPA TO-17 method [9]. Indoor and outdoor fractions of PM were actively sampled and determined following the reference procedure PN-EN 12341 standard [10]. Bioaerosols, defined as bacterial and fungal colony-forming units per cubic metre of air $\left(\mathrm{CFU} / \mathrm{m}^{3}\right)$, were collected using a six-stage Andersen cascade impactor (with aerodynamic cut-size diameters of 7.0, 4.7, 3.3, 2.1, 1.1 and $0.65 \mu \mathrm{m}$ ). Continuous measurements of $\mathrm{CO}_{2}$ concentrations both inside classrooms and outside the building were performed using automatic portable monitors (model 77535, Az Instruments). A detail procedures concerning determination of selected air pollutants has been presented in our previous articles $[8,11-13]$.

Statistical analyses were performed using the statistical package Statistica 13 (StatSoft). The non-parametric Mann-Whitney $U$ and Wilcoxon matched-pairs tests for VOCs, PM 
fractions, and bioaerosols were performed in order to test whether outdoor and indoor concentrations differed significantly, as well as whether the concentrations of compounds in older (I) and younger (II) children's classrooms differed significantly from one another. While for $\mathrm{CO}_{2}$ levels the parametric t-test was used. A statistical significance level of $\alpha=$ 0.05 was used throughout the study.

\section{Results and discussion}

\subsection{Volatile organic compounds}

The average concentrations of 16 determined VOCs outdoors 2.39 and $1.14 \mu \mathrm{g} / \mathrm{m}^{3}$ during winter and spring, respectively, as well as average $\Sigma V C_{16}$ indoors was $10.6 \pm 4.9 \mu \mathrm{g} / \mathrm{m}^{3}$ point to low concentrations of VOCs in the selected site. Analogically to outdoor concentration levels, indoors higher concentrations were observed in winter $16.1 \mu \mathrm{g} / \mathrm{m}^{3}$ (I) and $14.3 \mu \mathrm{g} / \mathrm{m}^{3}$ (II), with correspondence to $1.1 \mu \mathrm{g} / \mathrm{m}^{3}$ (I) and $1.5 \mu \mathrm{g} / \mathrm{m}^{3}$ (II) in spring. Figure 2 to presents the average indoor and outdoor concentrations of BTEX in older (I) and younger (II) children's classrooms as well as outside the building.

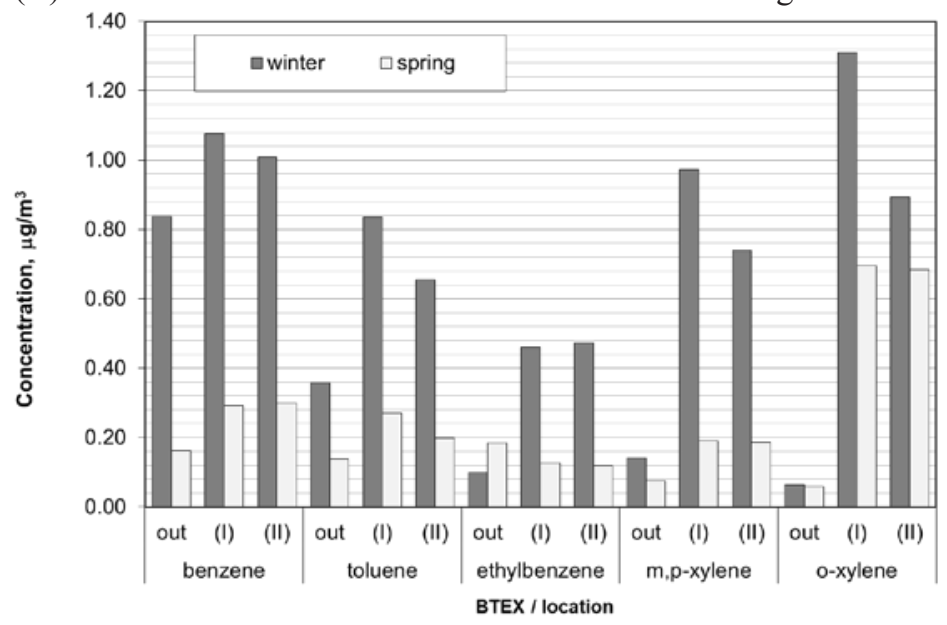

Fig. 2. The average concentrations of BTEX $\left(\mu \mathrm{g} / \mathrm{m}^{3}\right)$ during winter and spring campaigns

The concentrations of BTEX found inside the classrooms were higher than outdoor concentrations. The levels of many VOCs are typically higher inside the residences compared to outdoors because indoor VOC source emissions are stronger than the infiltration of outdoor air [14]. As shown in Figure 2, during winter season the concentrations of xylenes were significantly different $(p>0.05)$ between older (I) and younger (II) children classrooms. During the spring season indoor levels of BTEX in both classrooms are on the similar levels except toluene $(p<0.05)$.

Additionally toluene and xylenes are well correlated $R^{2}>0.7$, which point to common emission sources. Toluene and xylenes are strong compounds that are used in many household and industrial products. In the nursery schools children may breathe air contaminated with toluene and xylenes by use of glues, paints, rubbers and plasticmodelling cements. The other source of toluene and xylenes might be cleaning solvents used by nursery staff. Along with other solvents, common sources of ethylbenzene and oxylene might be paints, varnishes and to a lesser extent plastics, and synthetic fibre products e.g. in the coating of fabrics and papers [15]. 


\subsection{Particulate matter}

Polish legislation [16] specifies a 24-hour mean concentration of $\mathrm{PM}_{10}$ in ambient air, which is $50 \mu \mathrm{g} / \mathrm{m}^{3}$. For $\mathrm{PM}_{2.5}$, there is no corresponding short term (24-hour) limit, but there is an annual level of $25 \mu \mathrm{g} / \mathrm{m}^{3}$. The World Health Organization (WHO) is more strict in this regard; for $\mathrm{PM}_{2.5}$, it recommends a 24-hour average standard of $25 \mu \mathrm{g} / \mathrm{m}^{3}$ [17] and recommends applying to indoor spaces the same guidelines as for ambient air.

Simultaneously with indoor samples, outdoor samples of $\mathrm{PM}_{2.5}$ and $\mathrm{PM}_{10}$ were collected on playground areas. The average concentrations of $\mathrm{PM}_{2.5}$ and $\mathrm{PM}_{10}$ were $19.37 \mu \mathrm{g} / \mathrm{m}^{3}$ and $22.73 \mu \mathrm{g} / \mathrm{m}^{3}$ during spring, and did not exceeded WHO guidelines. While the concentrations during winter were $49.40 \mu \mathrm{g} / \mathrm{m}^{3}$ and $59.00 \mu \mathrm{g} / \mathrm{m}^{3}$, and exceeded WHO guidelines at $98 \%$ and $18 \%$ for $\mathrm{PM}_{2.5}$ and $\mathrm{PM}_{10}$, respectively.

The concentrations were significantly different between seasons as well as between older (I) and younger (II) children classrooms (Wilcoxon test, $\mathrm{p}<0.05$ ). PM concentrations were higher in older children's classrooms (Table 2). The TSP, $\mathrm{PM}_{10}$ and $\mathrm{PM}_{2.5}$ levels were significantly higher in older children classrooms $(p<0.05)$, while the $\mathrm{PM}_{1}$ levels were higher but only in winter. Other research reported an analogous relationship between the classrooms of younger and older children [18], and indicated a potential reason for this being the cumulative effect of three major conditions: high occupancy, poor ventilation and the intensive activities of children resulting in the PM resuspension phenomenon [19].

Table 2. Average levels of PM fractions $\left(\mu \mathrm{g} / \mathrm{m}^{3}\right)$ measured during occupancy periods inside the classrooms of younger and older children, as well as indoor/outdoor ratios.

\begin{tabular}{|c|c|c|c|c|c|c|}
\hline \multirow{2}{*}{$\begin{array}{c}\text { PM } \\
\text { fraction }\end{array}$} & \multicolumn{3}{|c|}{ Winter } & \multicolumn{3}{|c|}{ Spring } \\
\hline & (I) & (II) & $\begin{array}{cc}\text { Indoor/Outdoor } \\
(\mathrm{I} / \mathrm{O})_{\mathrm{I}} & (\mathrm{I} / \mathrm{O})_{\mathrm{II}}\end{array}$ & (I) & (II) & $\begin{array}{l}\text { Indoor/Outdoor } \\
(\mathrm{I} / \mathrm{O})_{\mathrm{I}} \quad(\mathrm{I} / \mathrm{O})_{\mathrm{II}}\end{array}$ \\
\hline $\mathrm{PM}_{1}$ & 102.11 & 49.04 & - & 45.62 & 49.04 & - \\
\hline $\mathrm{PM}_{2.5}$ & 125.69 & 67.65 & $3.30 \quad 1.11$ & 69.31 & 67.65 & $4.78 \quad 3.85$ \\
\hline $\mathrm{PM}_{10}$ & 166.12 & 81.49 & $3.79 \quad 1.10$ & 112.26 & 81.49 & $6.85 \quad 4.10$ \\
\hline TSP & 184.24 & 91.19 & - & 131.38 & 91.19 & - \\
\hline
\end{tabular}

The concentrations of $\mathrm{PM}_{2.5}$ (67.65 to $\left.125.69 \mu \mathrm{g} / \mathrm{m}^{3}\right)$ and $\mathrm{PM}_{10}\left(81.49\right.$ to $\left.166.12 \mu \mathrm{g} / \mathrm{m}^{3}\right)$ in all classrooms exceeded WHO guidelines, indicating the low quality of air in all classrooms (Table 2).

The average outdoor concentrations of $\mathrm{PM}_{2.5}$ and $\mathrm{PM}_{10}$ were typical for the Upper Silesia region [20-23]. Indoor mean concentrations of samples collected in Portuguese preschools were found to be at a similar level, e.g., $\mathrm{PM}_{1}, \mathrm{PM}_{2.5}, \mathrm{PM}_{10}$ and TSP were 33.08, $34.69,50.94$ and $85.81 \mu \mathrm{g} / \mathrm{m}^{3}$, respectively [4].

The I/O ratios were higher for larger fractions of $\mathrm{PM}_{10}$. The larger the particles are in optical diameter, the heavier they are and the more easily they are able to be deposited on floors and furnishing. Consequently, the influence of re-suspension on indoor particle concentrations increases with particle size. To understand the effect of size distribution on the measured PM concentrations, three different PM size ratios were used to characterize indoor air: $\mathrm{PM}_{1} / \mathrm{PM}_{2.5}, \mathrm{PM}_{2.5} / \mathrm{PM}_{10}$ and $\mathrm{PM}_{10} / \mathrm{TSP}$. The ratios calculated for each classroom were $0.72,0.75$ and 0.88 for $\mathrm{PM}_{1} / \mathrm{PM}_{2.5}, \mathrm{PM}_{2.5} / \mathrm{PM}_{10}$ and $\mathrm{PM}_{10} / \mathrm{TSP}$, respectively. All these ratios are high, showing high contribution of small particles.

\subsection{Bioaerosols}

Table 3 presents the average concentrations of bacterial and fungal aerosols collected in the indoor and outdoor air of rural nursery schools during the analysed winter and spring seasons. Bacteria levels (751-2588 $\left.\mathrm{CFU} / \mathrm{m}^{3}\right)$ were higher than fungi levels (156-1549 
$\mathrm{CFU} / \mathrm{m}^{3}$ ). The total concentrations of bacterial aerosols obtained in indoor air during the spring season were of a comparable level to those of the previous study conducted in urban nursery schools, which found levels of between 2545 and $2890 \mathrm{CFU} / \mathrm{m}^{3}$. However, the concentrations recorded inside the urban classrooms during the winter season were in some cases almost five times higher [12] than the results obtained in the rural nursery school. Other studies [24] concerning IAQ in two nursery schools in Bydgoszcz, conducted between April and February 2014, reported higher average concentrations of bacteria in the indoor air $\left(3697 \mathrm{CFU} / \mathrm{m}^{3}\right.$, range: $\left.1520-7780 \mathrm{CFU} / \mathrm{m}^{3}\right)$ and lower average concentrations in the outdoor air $\left(137 \mathrm{CFU} / \mathrm{m}^{3}\right.$, range: $\left.100-180 \mathrm{CFU} / \mathrm{m}^{3}\right)$. Research performed in Ankara, Turkey, underlined that, among indoor urban environments, the highest concentrations of total bacteria aerosols were observed in kindergartens, at 649 and $1462 \mathrm{CFU} / \mathrm{m}^{3}$ in the winter and summer seasons, respectively [25].

Table 3. Average concentrations of total bacterial and fungal colony-forming units per cubic metre in winter and spring season, as well as indoor/outdoor ratios.

\begin{tabular}{|c|c|c|c|c|c|c|c|}
\hline \multicolumn{2}{|c|}{ Season } & \multicolumn{3}{c|}{ Winter } & \multicolumn{3}{c|}{ Spring } \\
\hline \multirow{2}{*}{ Aerosol } & Location & $\begin{array}{c}\text { Average } \\
\text { concentration }\end{array}$ & SD & $\begin{array}{c}\text { I/O } \\
\text { ratio }\end{array}$ & $\begin{array}{c}\text { Average } \\
\text { concentration }\end{array}$ & SD & $\begin{array}{c}\text { I/O } \\
\text { ratio }\end{array}$ \\
\hline Bacterial & OUT & 751 & 223.4 & - & 1428 & 138.7 & - \\
\cline { 2 - 9 } aerosol, & (I) & 1990 & 301.9 & 2.65 & 2588 & 85.8 & 1.81 \\
\cline { 2 - 9 } CFU/m & (II) & 1596 & 288.8 & 2.12 & 2223 & 291 & 1.56 \\
\hline Fungal & OUT & 156 & 28.6 & - & 1549 & 222.4 & - \\
\cline { 2 - 8 } aerosol, & (I) & 172 & 34.7 & 1.1 & 670 & 93.7 & 0.43 \\
\cline { 2 - 9 } & (II) & 241 & 21.5 & 1.55 & 707 & 119.5 & 0.46 \\
\hline
\end{tabular}

The calculated average I/O ratios of bacterial and fungal aerosol levels according to groups of children for both winter and spring seasons, representing parallel indoor and outdoor samples collected for each sampling day, are given in Table 3. As can be seen from Table 3, the results indicate between two and four times higher indoor concentrations of bacterial aerosols than outdoor samples. The average I/O ratio calculated for all indoor and outdoor bacteria concentrations for the winter season was $>1$ so it can be concluded that the major sources of these bioaerosols are likely internal, such as building occupants (in this case children and their activities) as well as building materials that host microbiological growth (especially carpets).

According to Mann-Whitney U test results, a non-significant relationship was found between sample types (i.e., indoor (I) and (II) as well as outdoor bacteria levels) measured in both seasons $(\mathrm{p}>0.05)$.

\subsection{Carbon dioxide}

Based on the general guidelines concerning the quality of air inside non-residential buildings [5], the increase in $\mathrm{CO}_{2}$ concentrations in relation to $\mathrm{CO}_{2}$ concentration in outdoor air $\left(\Delta \mathrm{CO}_{2}\right)$ was measured during the children's occupation of both classrooms of each of the studied building. Figure 3 depicts the classification of IAQ in each nursery school building during the children's occupation during compulsory care/teaching hours (8:00-13:00). The indoor concentrations of $\mathrm{CO}_{2}$ revealed inadequate classroom air exchange rates. Most worryingly, during compulsory care/teaching hours, the air in the classrooms was often of low quality (IDA4). The highest contribution of IDA4 $(60.0 \%$ of compulsory care/teaching time) prevailed in the younger children's classroom (II).

Our research confirmed the enumerated conditions, moreover, our results point out differences between older (I) and younger (II) children's classrooms, which can become 
more significant if we link inadequate ventilation with the various patterns of children's activities.

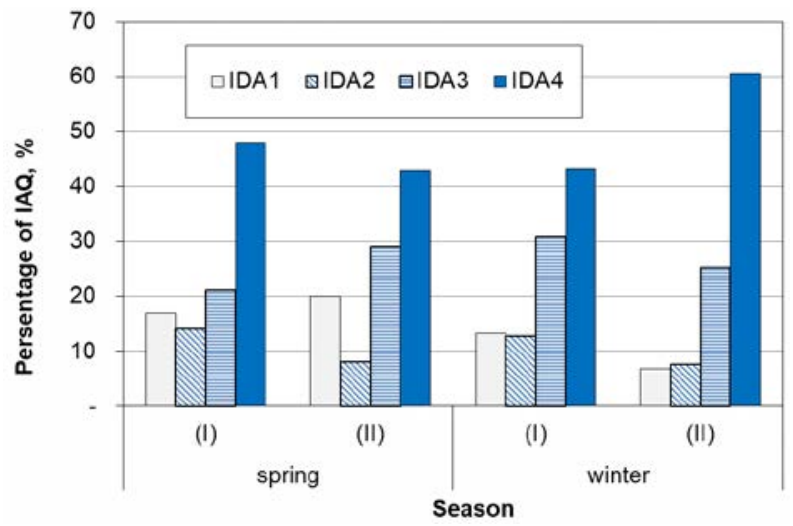

Fig. 3. Classification of IAQ (IDA) in nursery school building according to growth of $\mathrm{CO}_{2}$ concentration $\left(\triangle \mathrm{CO}_{2}\right)$.

\section{Conclusions}

Based on the results from this study, we draw some general conclusions here. The mean values of indoor VOC, PM, bacterial and fungal aerosol samples, as well as $\mathrm{CO}_{2}$ concentrations, were higher than in outdoor samples. The conclusion can therefore be drawn that indoor sources are the main contributors of IAQ in nursery schools. The results clearly indicate the problem of high $\mathrm{PM}_{2.5}$ and $\mathrm{PM}_{10}$ concentrations inside classrooms, exceeding the WHO short-term guidance values. Frequently monitored high levels of $\mathrm{CO}_{2}$ exceeding $1000 \mathrm{ppm}$ in relation to outdoor air (IDA4) also confirmed low indoor air quality inside classrooms, which is concerning in terms of the potential exposure effects on children's health.

The relationship between IAQ in older and younger children's classrooms was the most significant in $\mathrm{PM}\left(\mathrm{PM}_{1}, \mathrm{PM}_{2.5}, \mathrm{PM}_{10}\right.$ and $\left.\mathrm{TSP}\right)$ and $\mathrm{CO}_{2}$ concentrations. Compared to younger children, older children are more physically active, thus increasing PM resuspension. The highest $\mathrm{CO}_{2}$ concentration was observed in the classroom of younger children, who slept during the afternoon. In addition to the highest contribution of low IAQ - during $60 \%$ of teaching hours - the role of the afternoon nap seems significant.

This work was supported by the Faculty of Power and Environmental Engineering, Silesian University of Technology (statutory research). All the results used in this paper have received funding from the Polish-Norwegian Research Programme operated by the National Centre for Research and Development under the Norwegian Financial Mechanism 2009-2014 in the frame of Project Contract No Pol Nor/210247/20/2013.

\section{References}

1. EU Commission, Progress towards the Common European Objectives in Education and Training (2010/2011) (2011)

2. M. R. Ashmore, C. Dimitroulopoulou, Atmos. Environ. 43, 128 (2009)

3. T. Salthammer, E. Uhde, T. Schripp, A. Schieweck, L. Morawska, M. Mazaheri, S. Clifford, C. He, G. Buonanno, X. Querol, M. Viana, P. Kumar, Environ. Int. 94, 196 (2016) 
4. P. T. B. S. Branco, M. C. M. Alvim-Ferraz, F. G. Martins, S. I. V Sousa, Atmos. Environ. 84, 133 (2014)

5. PN-EN13779, Ventilation for Non-residential Buildings. Performance Requirements for Ventilation and Room- conditioning Systems (2008)

6. M. Griffiths, M. Eftekhari, Energy Build. 40, 556 (2008)

7. ASHRAE, Standard 62.1-2013 Ventilation for Acceptable Indoor Air Quality (2013)

8. A. Mainka, E. Brągoszewska, B. Kozielska, J. S. Pastuszka, E. Zajusz-Zubek, Atmos. Pollut. Res. 6, 1098 (2015)

9. SKC, VOC Method Update SKC Appendices to EPA Method TO-17 Determination of Volatile Organic Compounds (VOCs) in Ambient or Indoor Air (2012)

10. PN-EN12341, Ambient Air. Standard Gravimetric Measurement Method for the Determination of the PM10 or PM2,5 Mass Concentration of Suspended Particulate Matter (2014)

11. A. Mainka, B. Kozielska, AIMS Environ. Sci. 3, 858 (2016)

12. E. Brągoszewska, A. Mainka, J. S. Pastuszka, Aerobiologia (Bologna). 32, 469 (2016)

13. A. Mainka, E. Zajusz-Zubek, K. Kaczmarek, Int. J. Environ. Res. Public Health 12, 7990 (2015)

14. K. H. Jung, F. Artigas, J. Y. Shin, Environ. Monit. Assess. 173, 555 (2011)

15. Agency for Toxic Substances and Disease Registry ATSDR, 1 (2015)

16. Dz.U. Polish Journal of Laws, (2012)

17. WHO, Air Quality Guidelines for Particulate Matter, Ozone, Nitrogen Dioxide and Sulfur Dioxide (2006)

18. B. P. de Castro, G. de Souza Machado, G. F. Bauerfeldt, J. D. Nunes Fortes, E. M. Martins, Atmos. Environ. 104, 22 (2015)

19. A. Zwoździak, I. Sówka, M. Fortuna, Annu. Set Environ. Prot./Rocz. Ochr. Środowiska 15, 2022 (2013)

20. J. S. Pastuszka, W. Rogula-Kozłowska, E. Zajusz-Zubek, Environ. Monit. Assess. 168, 613 (2010)

21. K. Ćwiklak, J. S. Pastuszka, W. Rogula-Kozłowska, Polish J. Environ. Stud. 18, 579 (2009)

22. W. Rogula-Kozłowska, B. Błaszczak, S. Szopa, K. Klejnowski, I. Sówka, A. Zwoździak, M. Jabłońska, B. Mathews, Environ. Monit. Assess. 185, 581 (2013)

23. W. Rogula-Kozłowska, K. Klejnowski, P. Rogula-Kopiec, L. Ośródka, E. Krajny, B. Błaszczak, B. Mathews, Air Qual. Atmos. Heal. 7, 41 (2014)

24. Ł. Kubera, J. Studzińska, W. Dokładna, M. Małecka-Adamowicz, W. Donderski, Med. Pr. 66, 49 (2015)

25. S. Mentese, A. Y. Rad, M. Arisoy, G. Gullu, Indoor Built Environ. 21, 797 (2012) 